\title{
Depositional environment and reservoir quality assessment of the "Bruks Field," Niger Delta
}

\author{
Ayonma W. Mode ${ }^{1}$ Okwudiri A. Anyiam ${ }^{1} \cdot$ Solomon I. John ${ }^{1}$
}

Received: 18 October 2016/Accepted: 10 April 2017/Published online: 25 April 2017

(C) The Author(s) 2017. This article is an open access publication

\begin{abstract}
This study is a contribution to the understanding of the depositional environment and reservoir architecture of the "Bruks Field," Niger Delta, Nigeria. The objective is to use sequence stratigraphy and petrophysical evaluation in characterizing the reservoirs encountered in the study area. Well logs from six wells (B001, B002, B003, B009, B010 and B012-ST); biofacies data from wells B001 and B002; and a 3D seismic volume were analyzed to understand the spatial and temporal trends of reservoir sandstones, the environments of deposition, petrophysical properties of the F-sandstone and fault patterns on the structural map of the field. Log correlations show a considerable thickness of sands marked as fluvial. Results also show that the reservoirs are of foreshore, upper shoreface, lower shoreface, tidal channel and channel sands, which were deposited in a shallow marine setting. Two depositional sequences SEQ1 and SEQ2 were delineated with maximum flooding surfaces (MFS) 10.4 and $8.6 \mathrm{Ma}$, respectively. The depositional sequences are bounded with sequence boundaries (SB) dated 10.6, 10.36 and 7.4 Ma. The F-sand reservoir has an average net to gross thickness of 0.55 , effective porosity of $0.29 \mathrm{v} / \mathrm{v}$, permeability of $2506 \mathrm{mD}$ and water saturation of $0.14 \mathrm{v} / \mathrm{v}$. These values depict good reservoir quality, though the sand is deposited in tidal channels with the presence of heteroliths. The delineated faults composed of mainly growth faults, listric
\end{abstract}

Okwudiri A. Anyiam

okwudiri.anyiam@unn.edu.ng

1 Department of Geology, University of Nigeria, Nsukka, Nigeria fault, antithetic and synthetic faults that formed the hydrocarbon traps for the F-sand.

Keywords Reservoir architecture - Sequence stratigraphy · Depositional system

\section{Introduction}

A high degree of reservoir heterogeneity is usually associated with the paralic successions of the Niger Delta Basin (Asquith and Krygowski 2004), and this has been of major challenge for explorationists to adequately model the reservoirs and estimate hydrocarbon reserves (Darling 2005; Mode et al. 2013). Sands deposited in varying environments are characterized by different log trends, geometries and dimensions (Allen 1970). This shows that the physical characteristics of clastic reservoir rocks reflect a response of the complex interplay of processes operating in a depositional system. Thus, the reconstruction of environments of deposition of these varying clastic successions provides the optimum framework for describing and predicting reservoir quality and distribution (Allen 1965). There is also the need to approach the analysis of these sands with more robust interpretation techniques that that will enable better understanding of the reservoir heterogeneities so as to reduce uncertainties. This paper presents the results of the reservoir quality assessment carried out on the reservoir sands in the "Bruks Field," Coastal Swamp, Niger Delta, using the integration of sequence stratigraphy and petrophysical studies. The environments of deposition of the sands were inferred from the combined play of the stacking patterns and facies analysis which are in line some with previous studies in the area (Doust and Omatsola 1990; Ajaegwu et al. 2012). 


\section{Geologic setting and stratigraphy of the Niger Delta}

The study area (Fig. 1) is located within the Coastal Swamp Depo-belt Niger Delta. The Tertiary Niger Delta is situated on the continental margin of the Gulf of Guinea in equatorial West Africa. It is a clastic fill of about $12,000 \mathrm{~m}$ with an aerial extent of 75,000 sq. km. and extending more than $300 \mathrm{~km}$ from apex to the mouth (Evamy et al. 1978, Reijers et al. 1997). Sedimentation in the basin started in the late Paleocene-Eocene, when sediments began to build out beyond the troughs between the basement horst blocks at the northern flank of the present delta area and the open sea. The structural configuration and the stratigraphy of the Niger Delta are controlled by the interplay between rates of sediment supply and subsidence rate (Evamy et al. 1978; Doust and Omatsola 1990).

In the Niger Delta, three depositional settings indicate that deposition occurred during several regressive/transgressive episodes in overall progradational setting. These depositional settings can be subdivided into the lower overpressured marine Akata Formation which underlies the delta and it is composed of thick shale successions (potential source rock), turbidite sands (potential reservoirs in deep water) and minor amounts of clay and silt. Turbidity currents likely deposited the deep sea fan sands within the upper Akata Formation during development of the delta (Burke 1972). This lower shaley unit grades upward into an alternation of sandstone and shale (Agbada Formation), deposited under paralic conditions (Fig. 2). Most structural traps observed in the Niger Delta developed during syn-sedimentary deformation of the Agbada paralic sequence (Evamy et al. 1978). The primary seals are interbedded shales within the Agbada Formation. The paralic successions also grade into an upper series of massive sands and gravels (Benin Formation), deposited under continental conditions (Evamy et al. 1978; Weber 1986). It is a transitional series composed mainly of sand but with some shale.

\section{Materials and methods}

In this study, six well logs (B001, B002, B003, B009, B010 and B012-ST); biofacies data from wells B001 and B002; and a 3D seismic volume were analyzed to understand the thickness and lateral extent of the sands with their environments of deposition. The stacking patterns, system tracts and depositional sequences of the wells were delineated using sequence stratigraphic principles (Vail 1987; Van Wagoner et al. 1990). The biofacies data were used to mark in the candidate maximum flooding surfaces and sequence boundaries. Then, the wells were correlated both on the strike and dip sections to understand and map the extent of the sand intervals. A particular sand (F-sand) interval which is continuous in all the wells was subjected to petrophysical evaluation using the Techlog software. The main inputs of the module are gammaray (GR) log, bulk density; neutron and resistivity logs. It employs a Thomas and Stieber (1975) low resolution approach, a technique that was developed to estimate net to gross (N/G) and porosity of the sand laminations in heterolithic sand/shale successions with bed thicknesses below standard log resolution. The 3D seismic volume of the area was analyzed using PETREL 2010 software. Horizons and faults picking were carried out, and a structural map of the area was generated. A well to seismic tie was achieved with 0.84ms bulk time shift. Then, a polynomial velocity model equation was built and was used to convert the structural map in time to depth and into a structural model for the field.
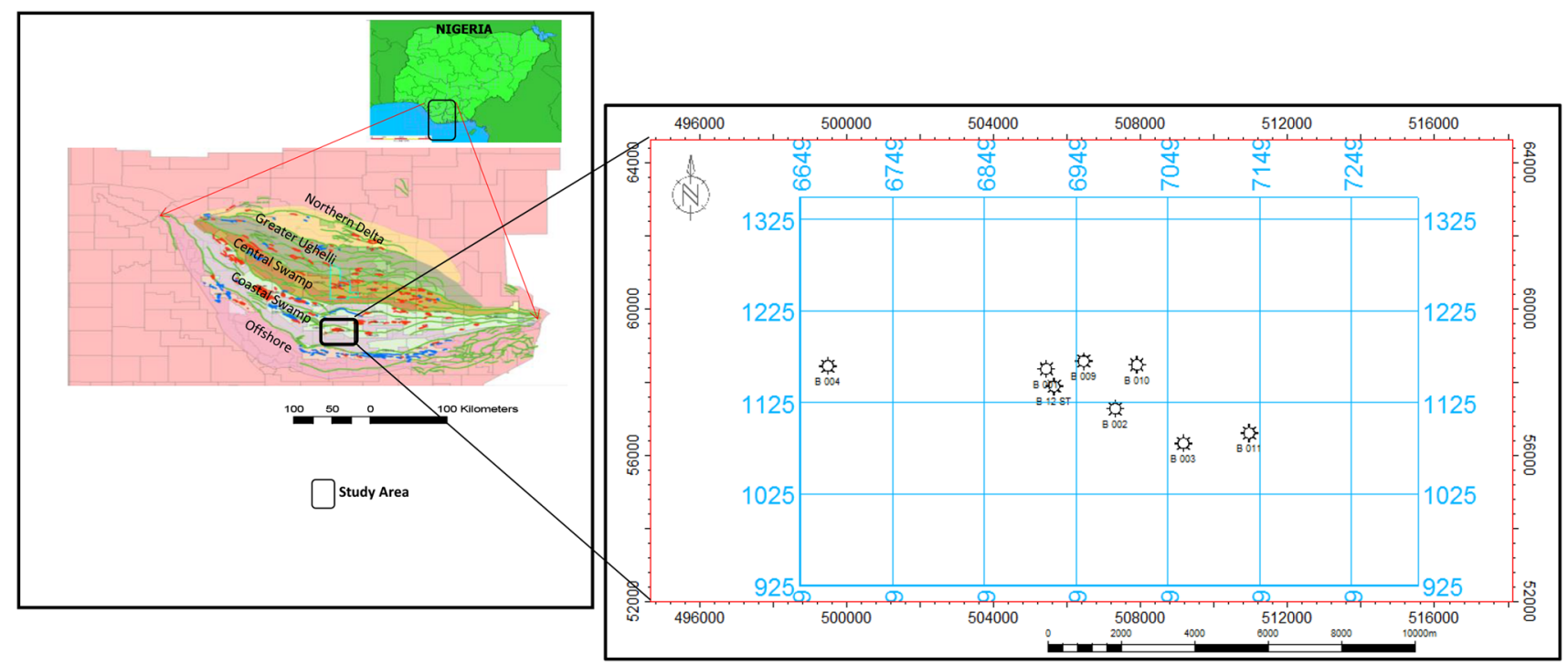

Fig. 1 Location map, showing the six study wells in the Coastal Swamp Depo-belt, Niger Delta 

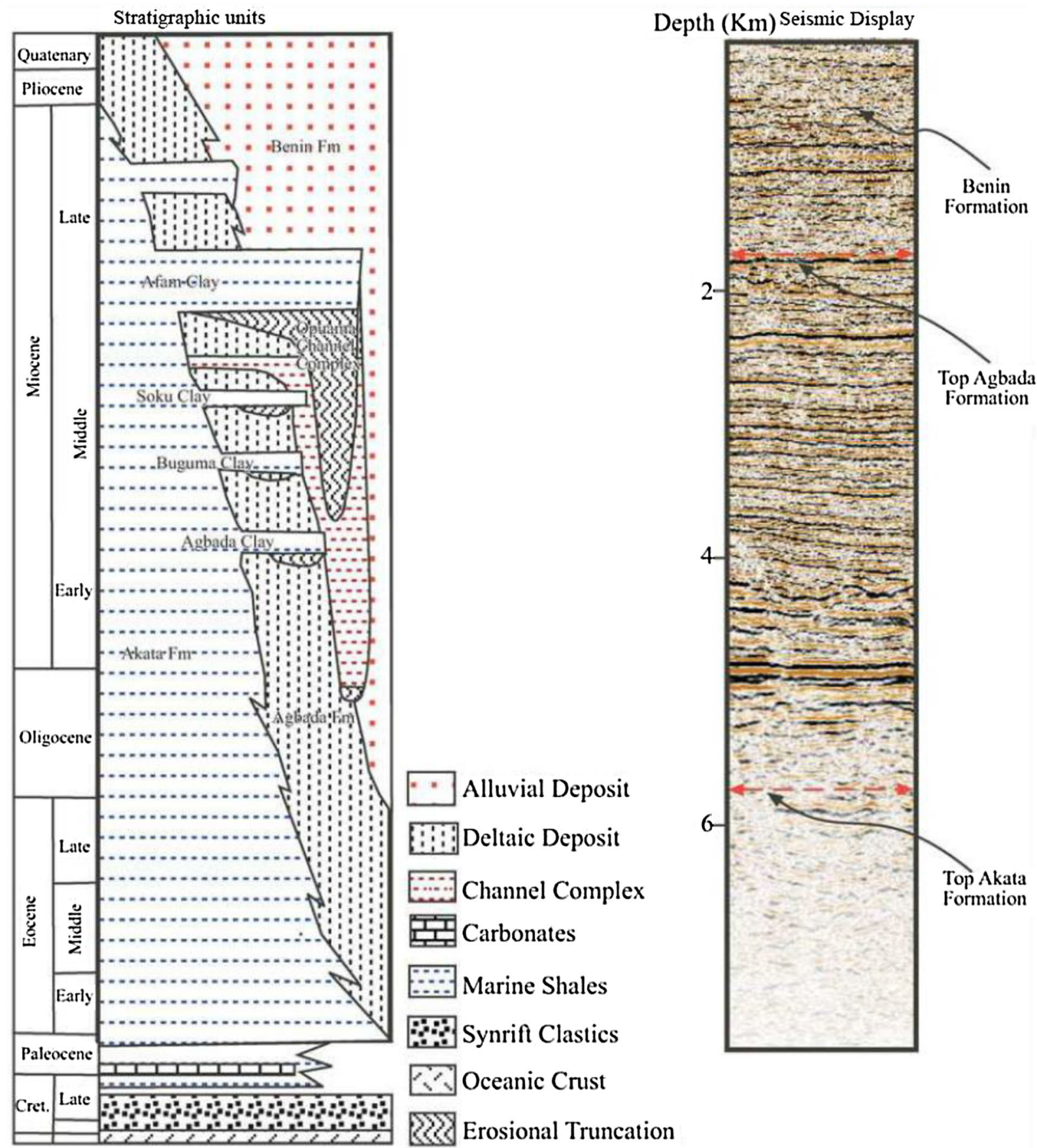

Fig. 2 Stratigraphy of the Niger Delta and variable density seismic display of the main stratigraphic units in the outer and thrust belt and the main reflectors (Lawrence et al. 2002)

\section{Results and discussion}

\section{Wireline facies interpretation}

The environments of deposition of the reservoirs were predicted using the GR log motifs according to Kendall (2003) and biofacies data (see Fig. 3a-d). These reservoirs were interpreted as shoreface, tidal channel and distributary channel sands (Fig. 3a, b).

Shoreface sand (SFS)

The sands have coarsening upward and symmetrical signatures. These are reworked deposits from longshore 
a
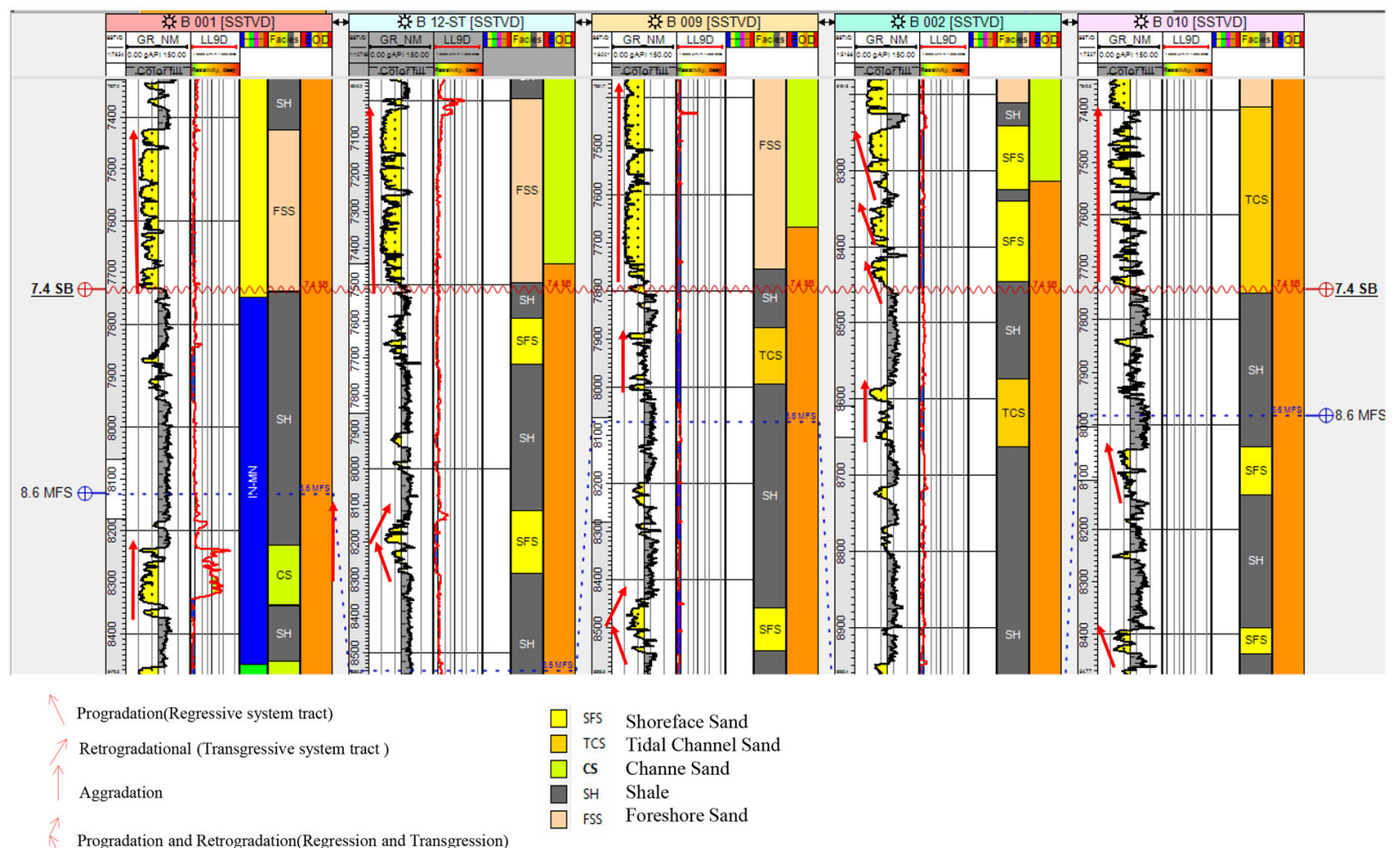

b
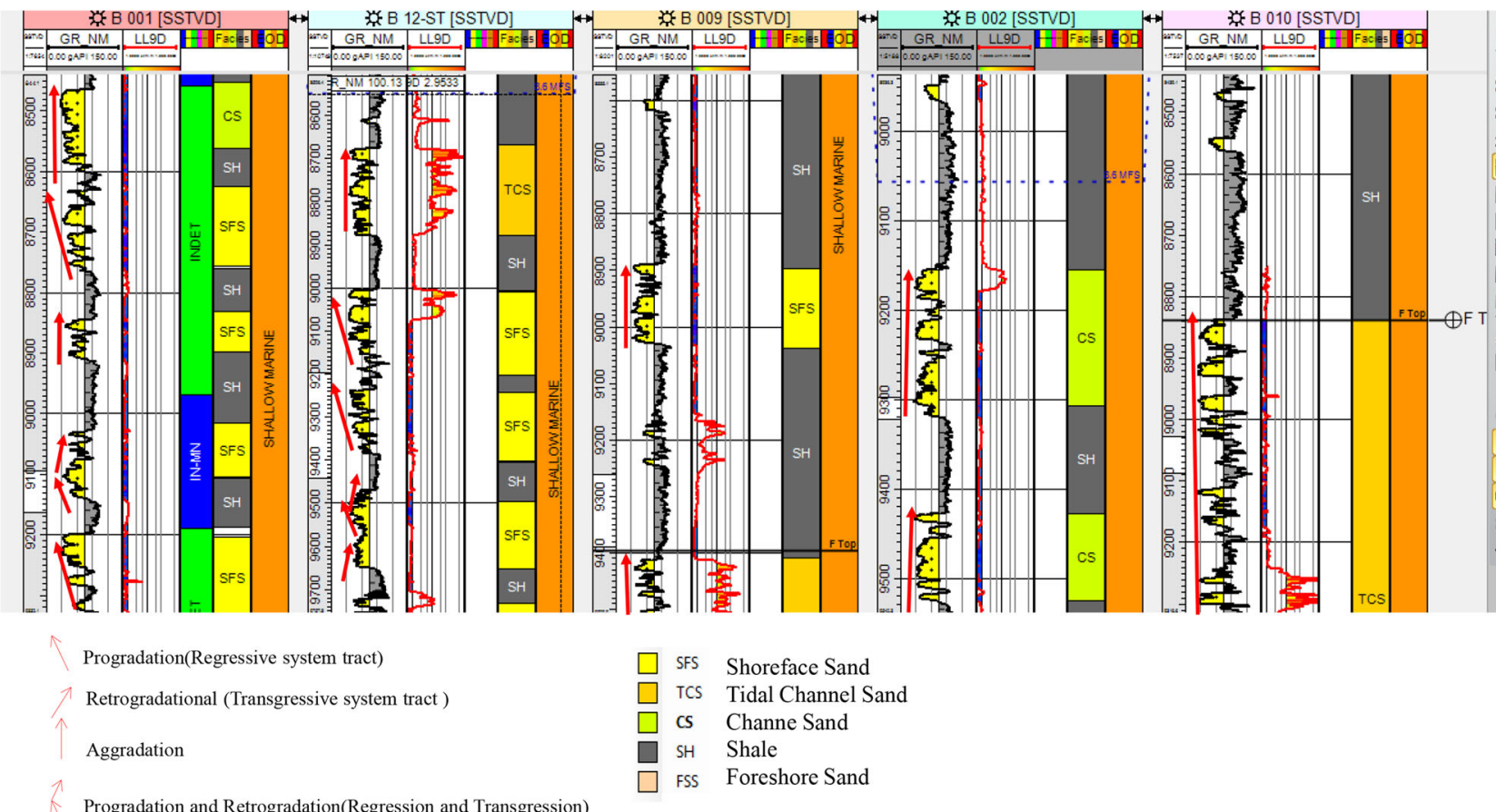

Fig. 3 Depositional environment discrminations of the a $7500-8500 \mathrm{ft}$ interval, b $8500-9300 \mathrm{ft}$ interval, c $9600-10,300 \mathrm{ft}$ interval and d 10,300-11,000 ft interval for the Bruks field

currents. The upper part of it is the upper shoreface while the lower part is the lower shoreface facies. Upper shoreface deposits occur around the shelf and also on the outer shelf terrace (5-few $10 \mathrm{~s}$ of $\mathrm{m}$ ) (Helland-Hansen and Hampsen 2009), and they are of good reservoirs because of high porosity and coarse grains. Lower shoreface has 


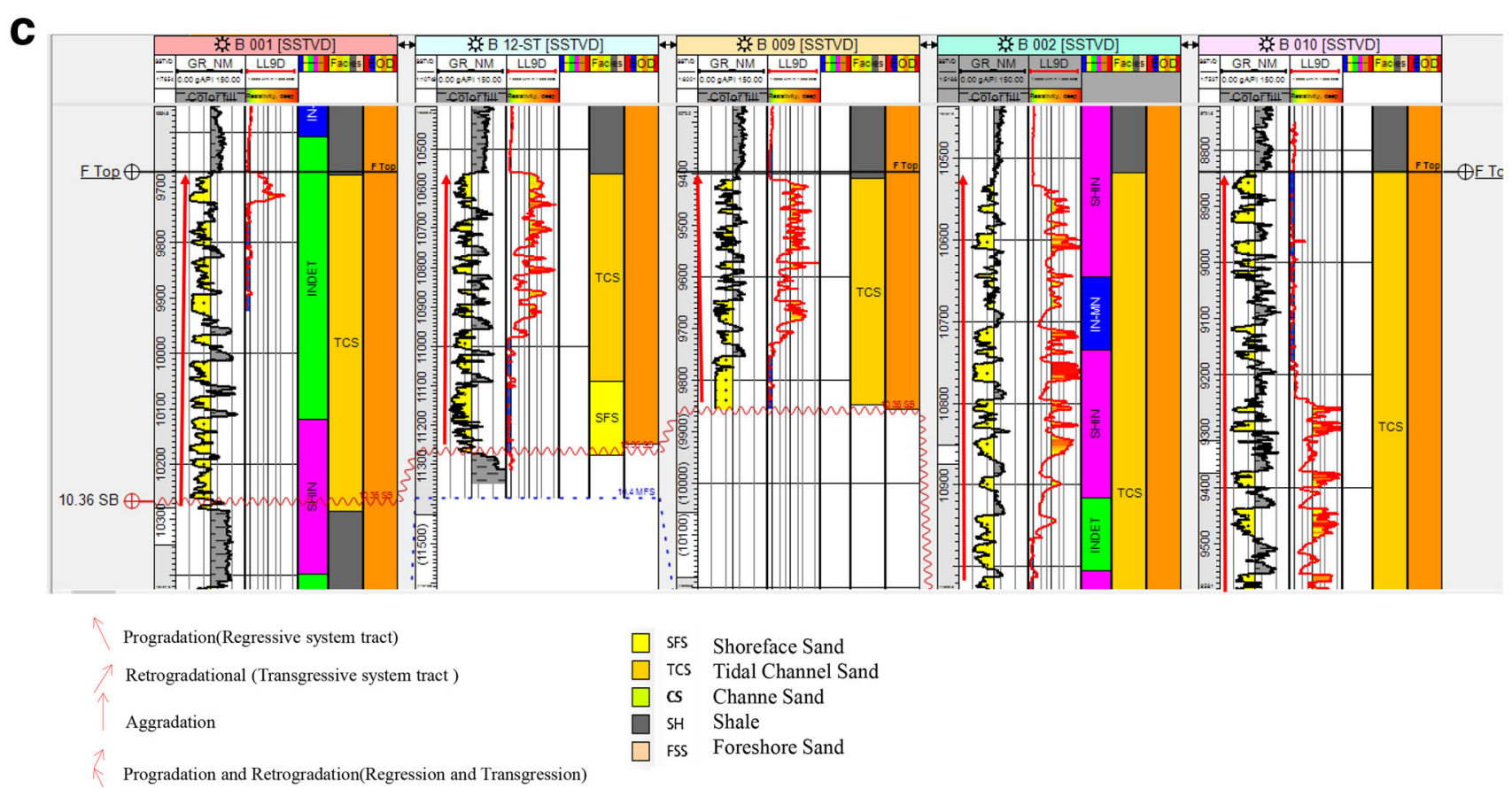

d

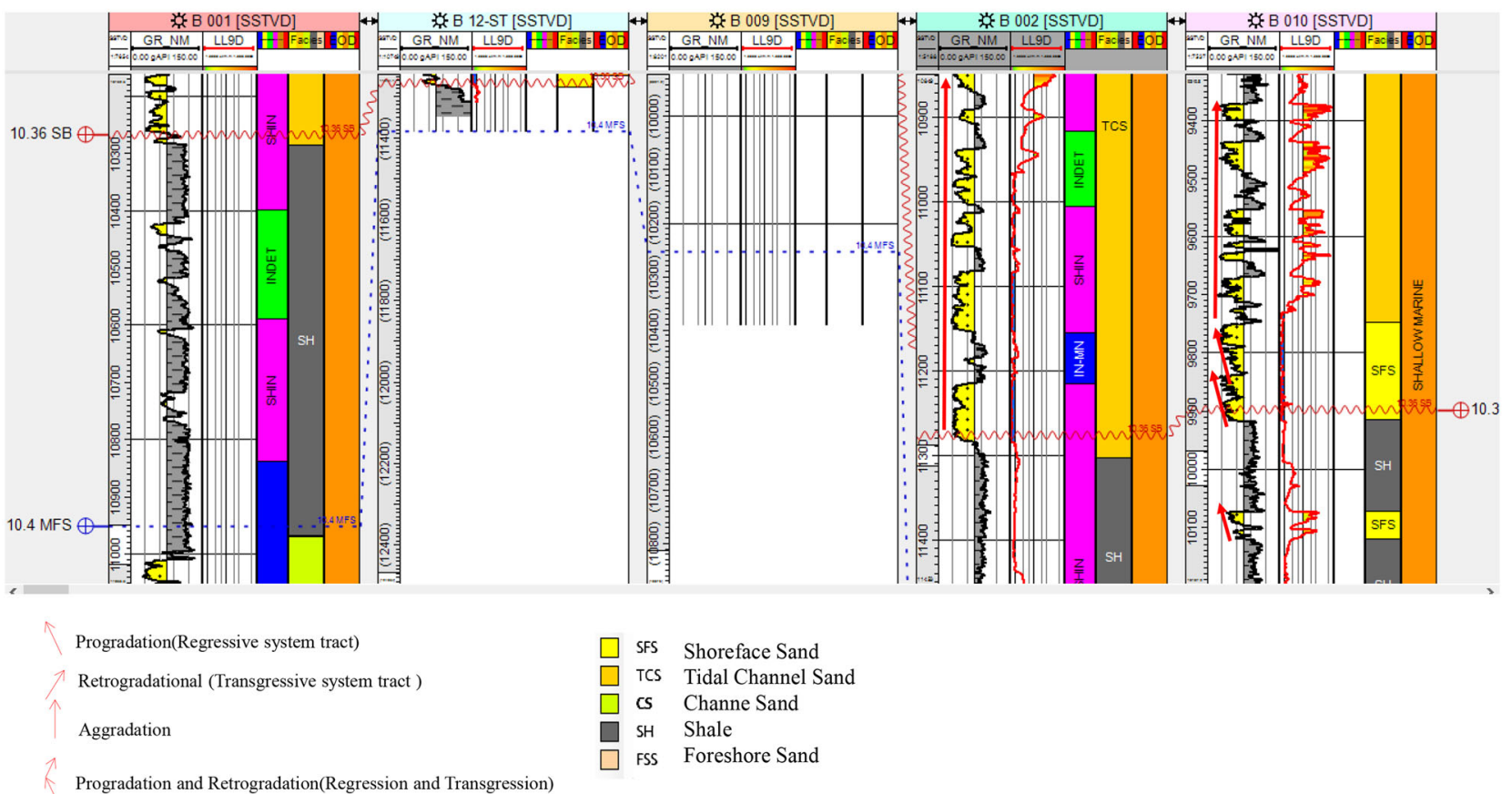

Fig. 3 continued

alternation of sand and shale forming a serrated shape. They are usually deposited in the outer neritic at a depth range of $20-50 \mathrm{~m}$. Generally the shoreface deposits are wave dominated with good winnowing effect. The paleoenvironment of the funnel-shaped succession belongs to the prograding delta (Selley 1998).
Tidal channel sand $(T c S)$

The sands show erosional based blocky motifs with intercalations of shales. This depicts the shoreline and basinal directional flows of the tidal currents; depositing sands; and mud/shales, respectively. The mud/shale deposits are 


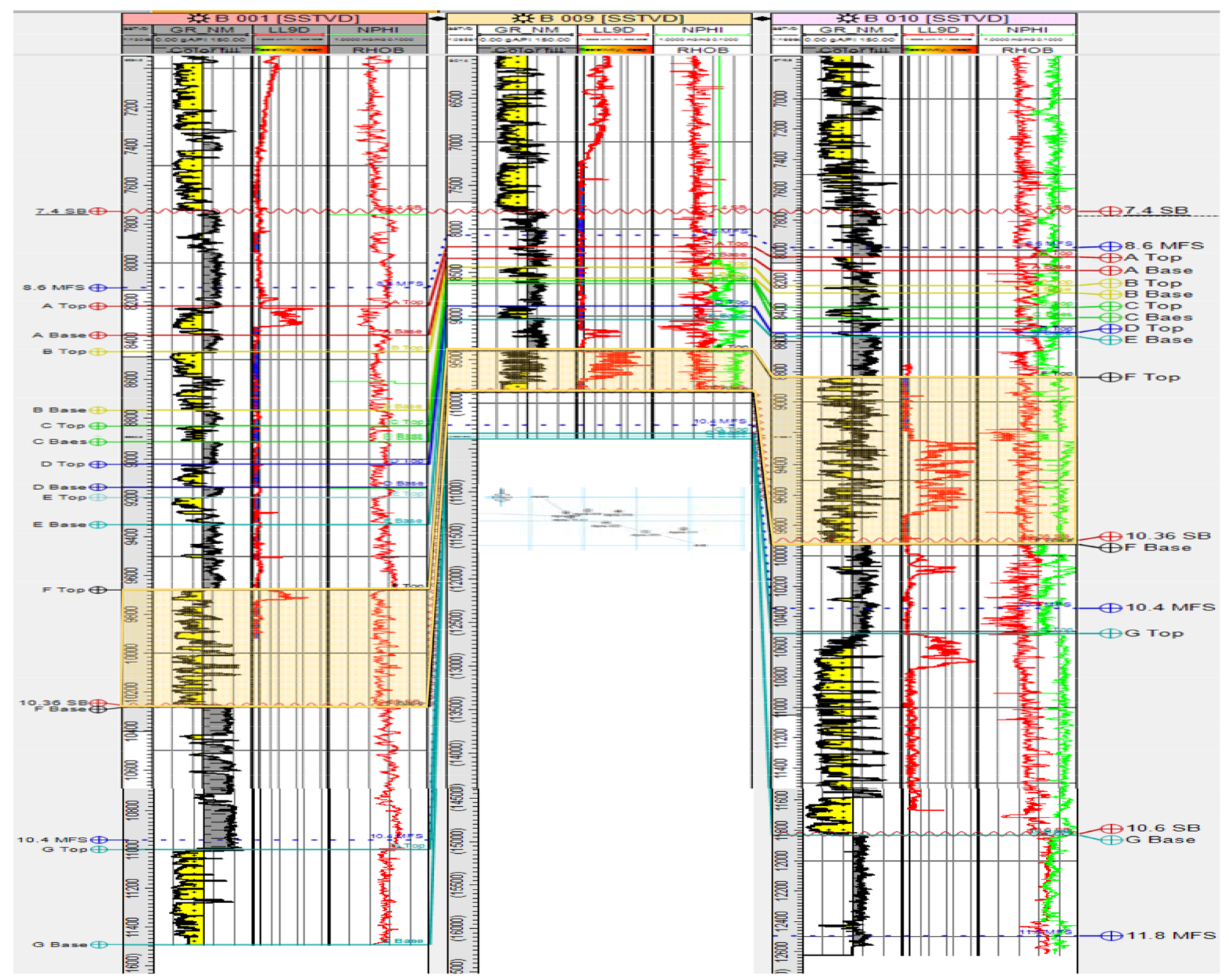

Fig. 4 Reservoir correlations for Bruks Field along the strike direction

thinner than the sand deposits. Due to the reworking by the tide, the motifs are serrated. Tidal channel deposits are usually deposited at the marginal marine (mid-delta and estuarine). Also due to their reworking, some of the portions showed coarsening upward motif. The tidal reservoirs are poorer in quality than other shallow marine reservoirs because of the presence of numerous mud laminae deposited as the channel is drowned by the tidal current.

\section{Distributary channel sand (DcS)}

The sand lithologies identified with blocky (boxcar) and fining upward signatures are classified as channel sands. The sand deposits show aggradational signatures and are braided point bar sands. The blocky GR motif is an evidence of distributary channel fills which are also associated with fines. Distributary channel sands are good reservoir because they are of relatively high energy porous and clean. (.i.e., have low shale content). The boxcar-shaped gamma-ray log indicates the truncation or rapid termination of deposition at the upper and bottom boundaries. The boxcar-shaped deposits in this study can be associated with the delta distributary channel successions (Selley 1985).

The quality of these reservoir sands is strongly linked to their depositional systems. For example, sands of the tidally influenced channel sands are not laterally continuous, but are restricted within the channels in a vertical stack system and correlated along the strike and dip sections in the field (Figs. 4, 5). With the high degree of wave action that results in proper winnowing of the foreshore and shoreface sands, their reservoir quality is expected to be good to excellent and laterally continuous. On the other hand, the fluvial channel sands of the braided systems have relatively better quality reservoirs than meandering systems because of the presence of heteroliths and clay plugs in meandering channels. Also, the braided channels are usually laterally continuous within the channel and with vertical stacking pattern with few baffles. The tidal channel 


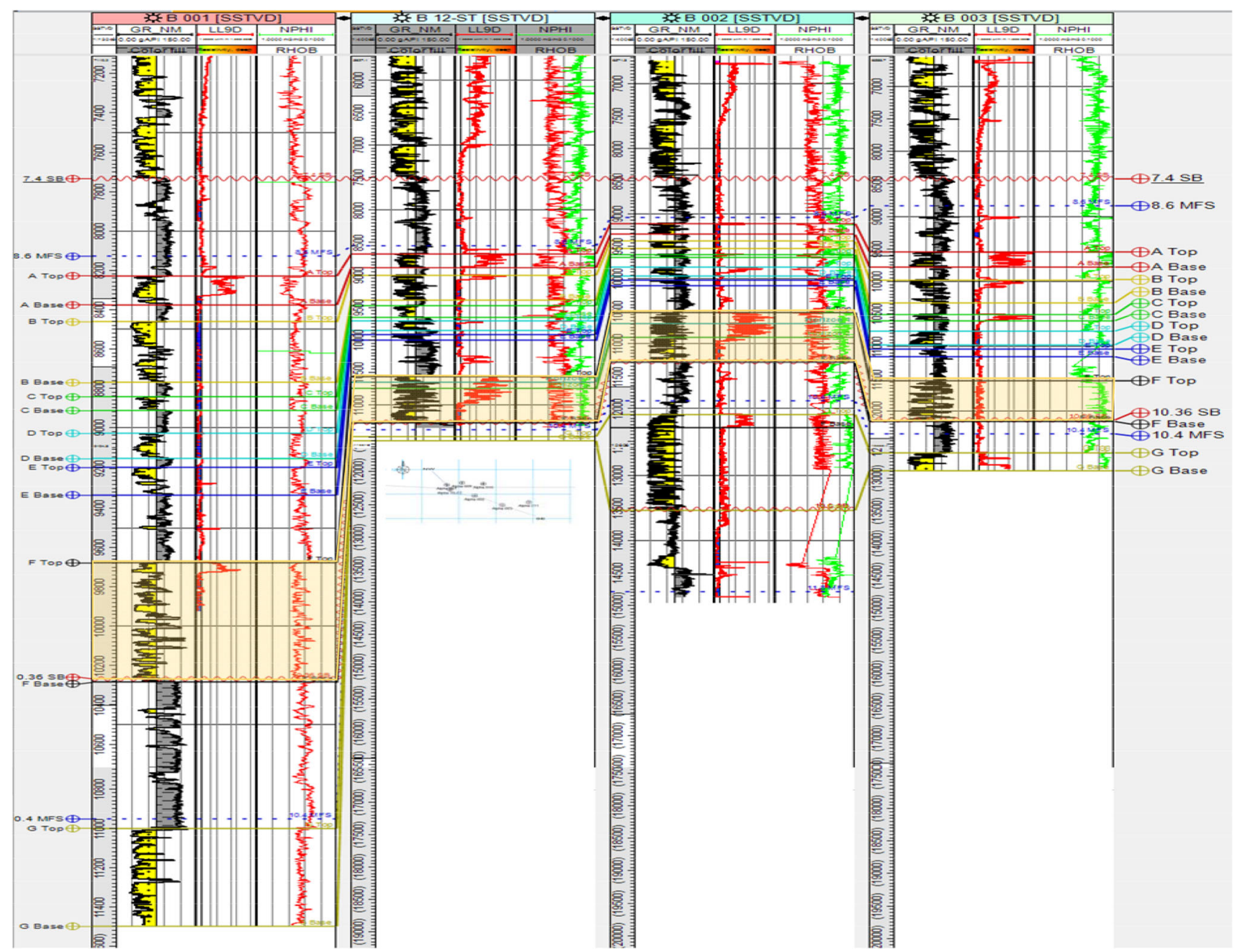

Fig. 5 Reservoir correlations in Bruks Field along the dip direction

sands usually posses fair to good reservoir quality due to their high degree of heterogeneity. The general environments of deposition for these sands are inferred to be shallow marine with fluvio-deltaic inputs. The understanding of the varying sand depositional environments with their associated reservoir quality prediction enables better characterization of reserves and the design of optimum reservoir management procedures.

\section{Sequence stratigraphic analysis}

From the sequence stratigraphic analysis, the two wells with biofacies data (B001 and B002) were used as control in establishing the key surfaces. Two major depositional sequences (SEQ1 and SEQ2) were mapped and delineated across the field and are located within the paralic Agbada Formation of the Niger Delta. These depositional sequences are defined by three sequence boundaries (SB) dated 10.6, 10.36 and 7.4 (Figs. 4, 5) and three maximum flooding surfaces (MSF) dated 11.8, 10.4 and $8.6 \mathrm{Ma}$ (middle Miocene). The sequence boundaries were identified by the abrupt swallowing (i.e., overlying of thick sand on shale) and very low foraminifera abundance while the maximum flooding surfaces were marked by high foraminifera and pollen abundances (P770_Base-P770_Top and P784_Base-P784_Top; F9600) (Galloway 1989). These surfaces correspond with the regional Niger Delta chronostratigraphic chart, and they gave rise to the corresponding lowstand, transgressive and highstand systems tracts.

\section{Lowstand system tract (LST)}

The lowstand system tract (LST) lies on the sequence boundary (SB) and is seen on the seismic as discontinuous reflectors or reflectors wrapped inside another reflector. The LST shows mainly aggradation packages (blocky) which indicates that they are incised valley fills (Fig. 6a, b). The horizons are not continuous and distinct. In some cases, LST is recognized as channel fills which are

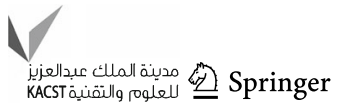


a

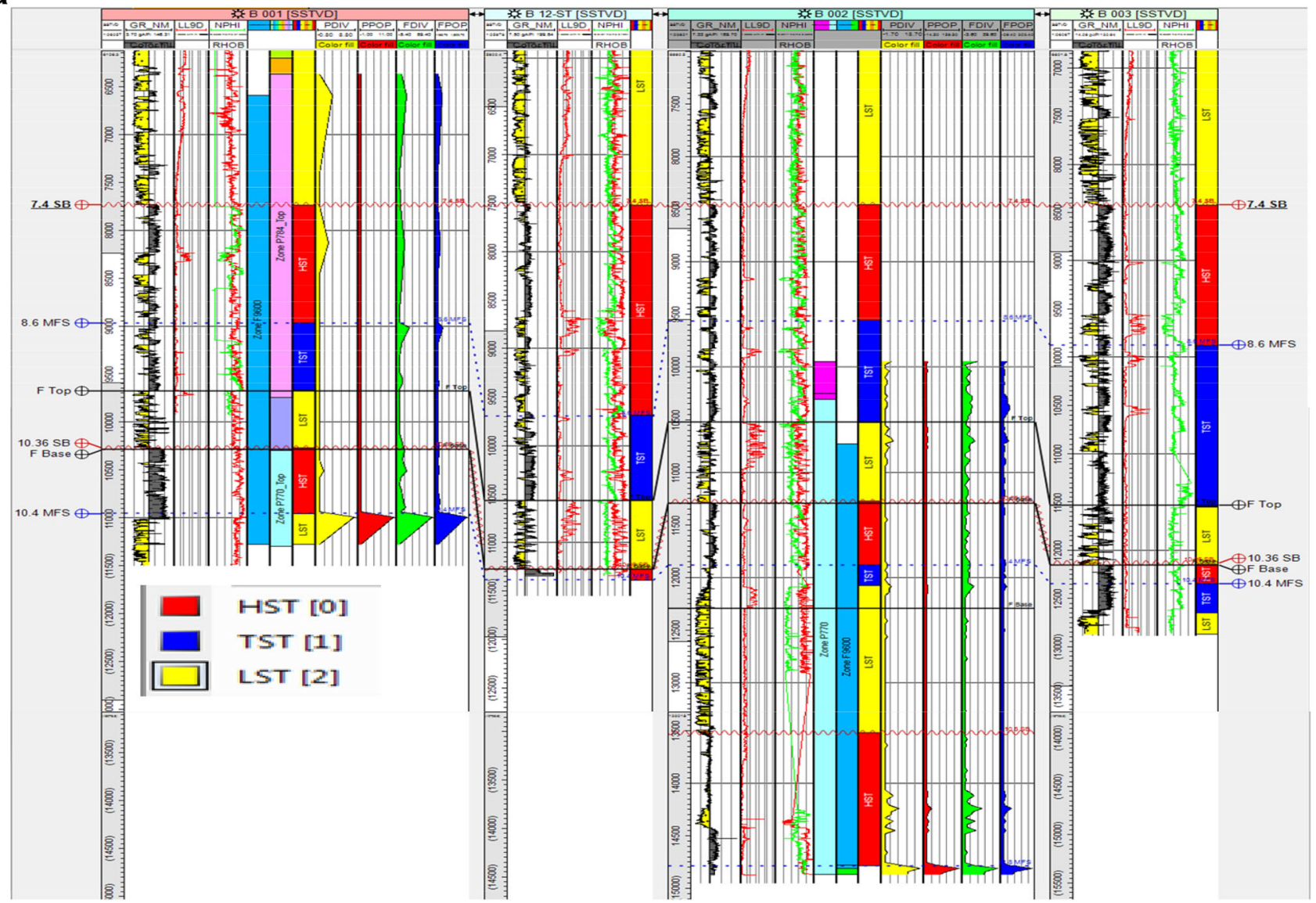

Fig. 6 a Sequence stratigraphic framework of upper interval across field. b Sequence stratigraphic framework of the lower interval across field

wrapped in another reflector and do not exceed or cut across the reflector.

\section{Transgressive systems tract}

The point at which the evidence of uniform sand progradation ends above the SB till the maximum flooding surface (MFS) is inferred as the TST. The TST is recognized by its continuous reflectors. Though the acoustic impedance contrast of the blue and red loop may not be distinct, sometimes they tend to be almost faint. It is a parasequence of shale interspersed with sand, and it is bounded on the top by MFS and below by maximum regressive surface (MRS). From the gamma-ray log displayed on the seismic (Figs. 6a, 8), the TST is packages that are predominantly shale with streaks of sand with fining upward parasequence packages in between them.

\section{Highstand system tract (HST)}

The highstand system tract (HST) is distinct on the seismic due to its great acoustic impedance of the sands alternating with low acoustic impedance contrast of the mud-rich intervals. The sands show prograding packages in between shales (Fig. 6a, b). The basal limit of this systems tract is the maximum flooding surfaces (MFS), and it is also bounded at the top by sequence boundary (SB).

\section{Depositional sequence one (SEQ1)}

This is the oldest depositional sequence, and it is bounded by sequence boundaries 10.6 and $10.36 \mathrm{Ma}$ at the base and top, respectively (Fig. 6a, b). It has a maximum flooding surface dated 10.4 Ma which caps the transgressive system tract. The 10.6 Ma sequence boundary (SB) is the oldest and the deepest in the field, whereas the 10.3 Ma SB caps the depositional sequence and they are mapped in wells B001, B002, 009, B010 and B012-ST.

The reservoir sands of this depositional sequence are mainly the foreshore, shoreface and distributary channel sands of the lowstand systems tract deposited in marginal and shallow marine settings. The sandstone reservoir unit is capped by thick shale interval of the 10.4-Ma maximum flooding surface that forms the top seal. In this study, the 


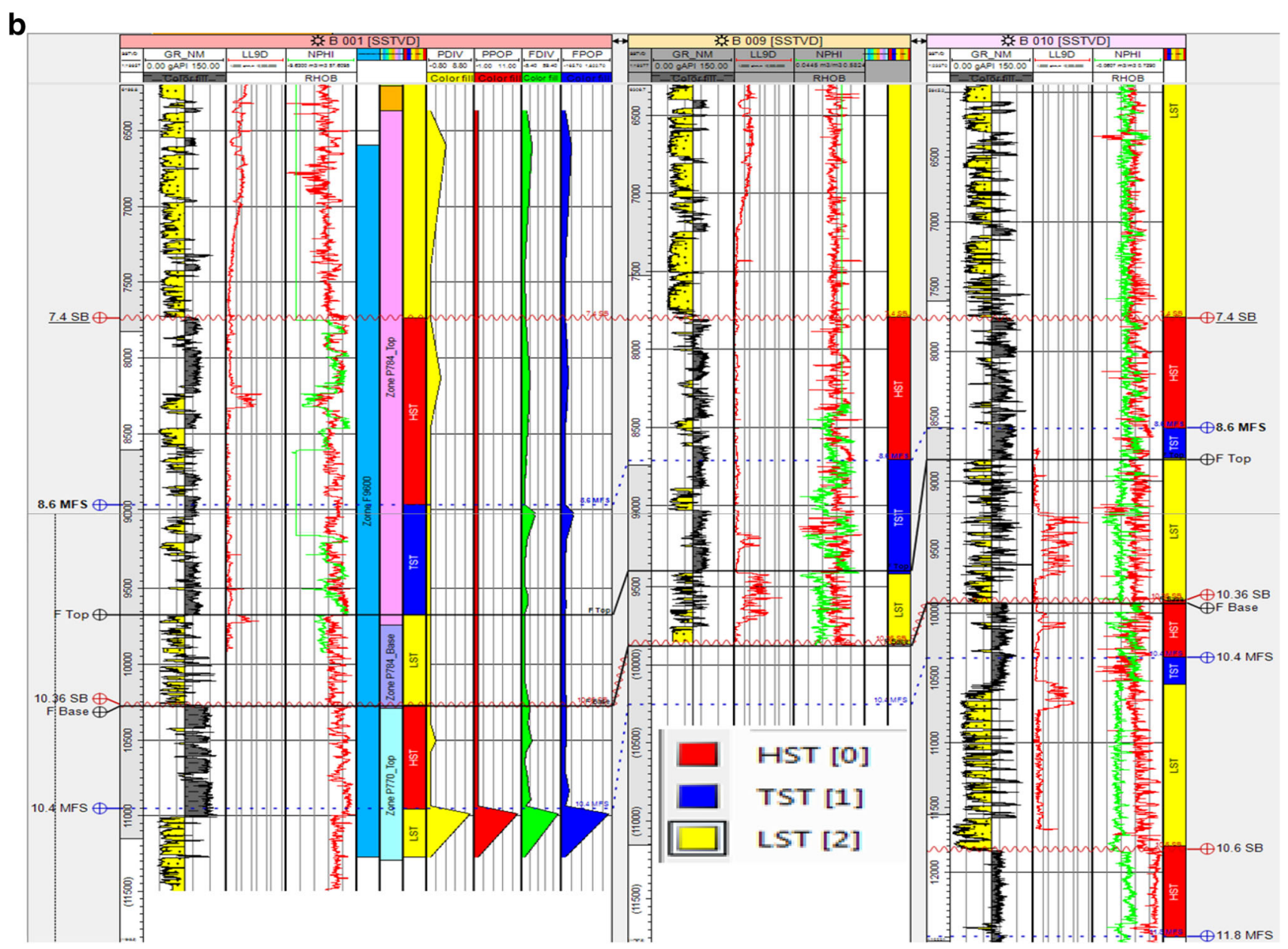

Fig. 6 continued

Table 1 Petrophysical evaluation of the F-sand in the wells of the field

\begin{tabular}{|c|c|c|c|c|c|c|c|c|c|c|c|}
\hline Well & Sand & $\begin{array}{l}\text { Top } \\
\text { (ft) }\end{array}$ & $\begin{array}{l}\text { Base } \\
(\mathrm{ft})\end{array}$ & $\begin{array}{l}\text { Gross thickness } \\
\text { (ft) }\end{array}$ & $\begin{array}{l}\text { Net thickness } \\
\text { (ft) }\end{array}$ & $\begin{array}{l}\text { NTG } \\
\text { thickness }\end{array}$ & $\begin{array}{l}\text { POR } \\
(\mathrm{v} / \mathrm{v})\end{array}$ & $\begin{array}{l}\text { Vsh } \\
(\mathrm{v} / \mathrm{v})\end{array}$ & $\begin{array}{l}\mathrm{Sw} \\
(\mathrm{v} / \mathrm{v})\end{array}$ & $\begin{array}{l}\mathrm{SH} \\
(\mathrm{v} / \mathrm{v})\end{array}$ & $\begin{array}{l}\mathrm{K} \\
(\mathrm{mD})\end{array}$ \\
\hline B_001 & F-sand & 9660 & 10,280 & 620 & 490 & 0.79 & 0.27 & 0.30 & 0.22 & 0.78 & 558 \\
\hline B_002 & & 10,520 & 11,300 & 780 & 340 & 0.44 & 0.30 & 0.30 & 0.13 & 0.87 & 2540 \\
\hline B_009 & & 9400 & 9780 & 380 & 200 & 0.53 & 0.30 & 0.35 & 0.15 & 0.85 & 1908 \\
\hline B_010 & & 9650 & 10,300 & 650 & 290 & 0.45 & 0.31 & 0.37 & 0.10 & 0.90 & 4960 \\
\hline B_012ST & & 10,550 & 11,300 & 750 & 420 & 0.57 & 0.29 & 0.33 & 0.12 & 0.88 & 2568 \\
\hline Average & & & & 636 & 348 & 0.55 & 0.29 & 0.33 & 0.14 & 0.85 & 2506 \\
\hline
\end{tabular}

aggradational highstand sands of the shelf were not prominent, but are observed to be muddy, typical of deeper setting.

\section{Depositional sequence two (SEQ2)}

The second depositional sequence directly overlies the depositional sequence one, and it is bounded by $10.36 \mathrm{Ma}$ sequence boundary at the base and 7.4-Ma sequence boundary at the top. This depositional sequence has a maximum flooding surface dated $8.6 \mathrm{Ma}$ that caps the transgressive systems tract (Fig. 6a, b). The 7.4-Ma sequence boundary caps this sequence, and it is the youngest sequence boundary dated in the field. This SB also marks the onset of the fluvio-deltaic Benin lithostratigraphic unit of the delta. Six reservoir units (A-sand to G-sand) were delineated within this depositional sequence, but the F-sand reservoir is the reservoir of interest because 


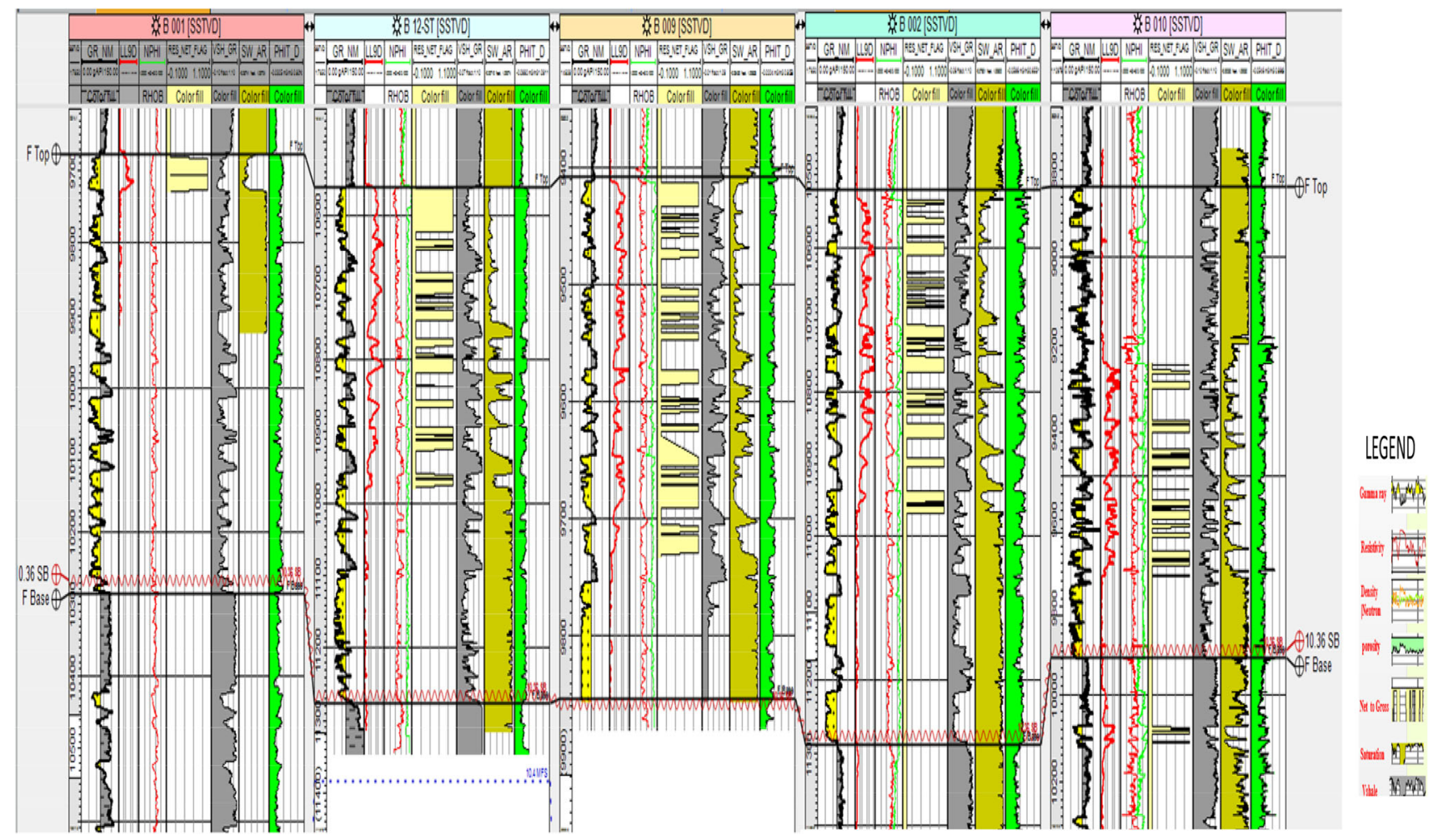

Fig. 7 Petrophysical logs generated for the F-sand reservoir

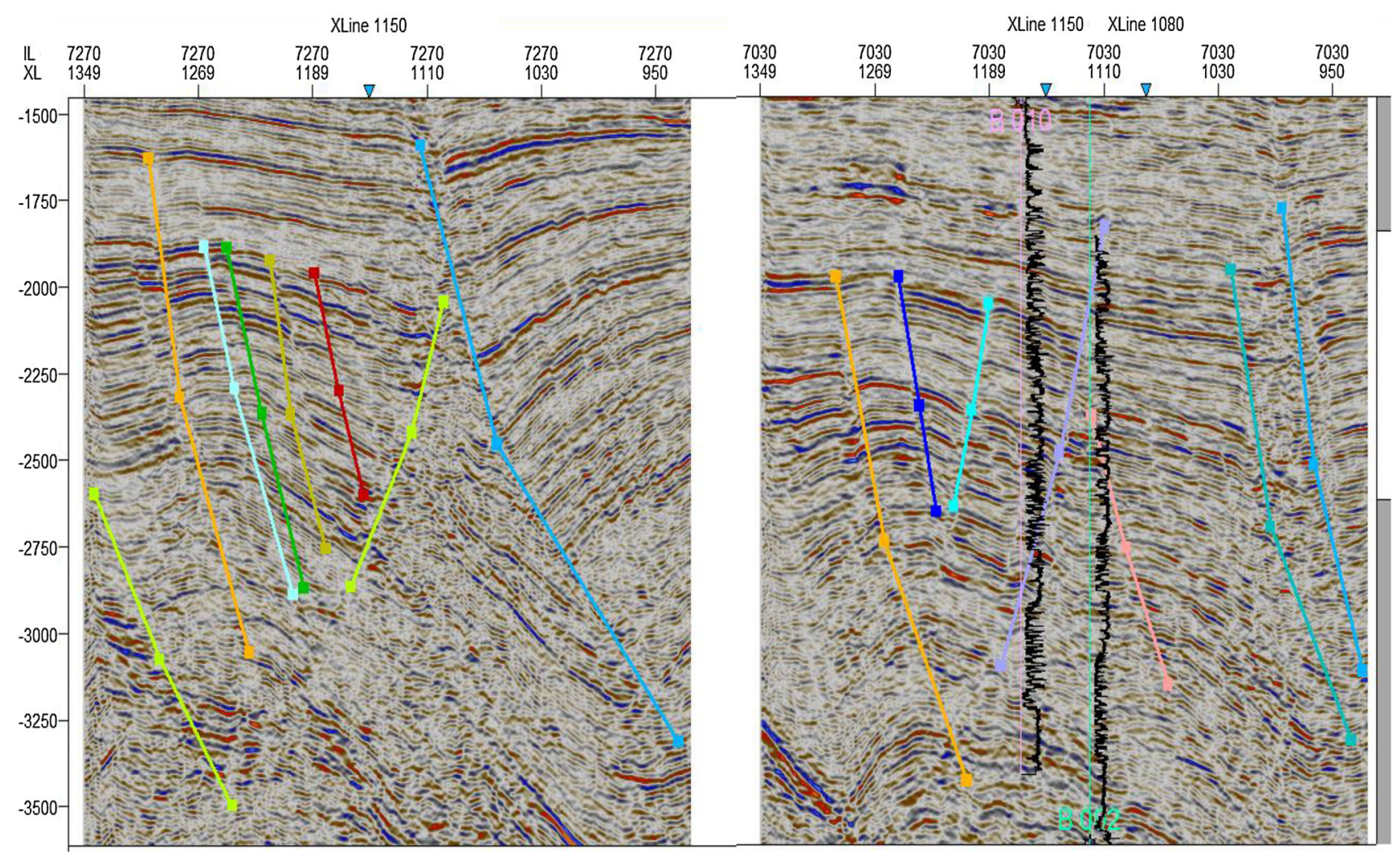

Fig. 8 Fault trends mapped in the study area 


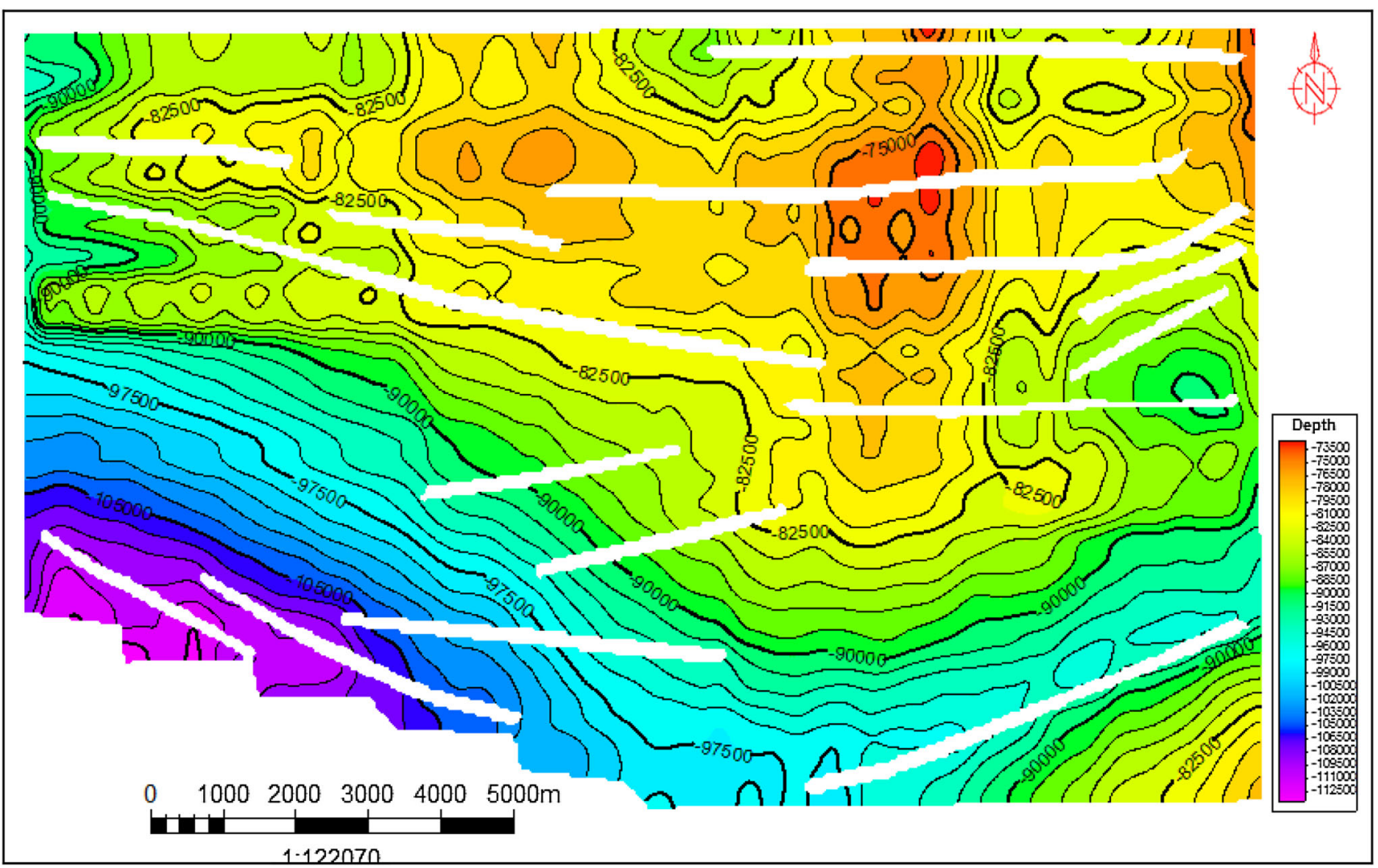

Fig. 9 Structural map for the F-sand top in depth, showing the numerous faulted anticlines

of its thickness and lateral extent across the wells (Figs. 4, 5). The F-sand reservoir is a tidally influenced channel sand of lowstand systems tract intervals of sand/shale heteroliths.

\section{Reservoir formation evaluation}

The petrophysical evaluation was carried out only on the F-sand reservoir in order to evaluate the continuity of its reservoir quality. The net reservoir thickness of the F-sand ranges from $200 \mathrm{ft}$ (Well B009) to $490 \mathrm{ft}$ (Well B001) with an average net thickness of about $348 \mathrm{ft}$ (Table 1). The reservoir has a moderate sand package with a net to gross of about 0.55 and $0.33 \mathrm{v} / \mathrm{v}$ volume of shale. As expected in a tidally influenced system, where shale and clay alternate with sands, the high volume of shale may have affected the interlayer porosity and permeability of the gross thickness. The F-sand has an average porosity and permeability value of $29 \%$ and $2506 \mathrm{md}$, respectively (Table 1). These porosity-permeability values confirm that the sand has moderate to good reservoir quality. The average water saturation of $14 \%$ which translates to $85 \%$ hydrocarbon saturation (oil) is an indication that the F-sand reservoir is charged with a significant volume of hydrocarbons with an oil-water contact (OWC) at a depth of about $9740 \mathrm{ft}$.
From the generated petrophysical logs (Fig. 7), and tabulated results (Table 1), the reservoir quality of the F-sand increases from well B001 (27\% porosity, $558 \mathrm{mD}$ permeability) to well B10 ( $31 \%$ porosity, $4760 \mathrm{mD}$ permeability). Though, there is reduction in the net to gross thickness of the sand from well B001 to well B002 (Table 1; Fig. 7), the average reservoir quality is good. Its good reservoir quality shows that the energy of the tidal currents may have increased distally with an input of the shallow marine wave actions in a manner that cleaner sands were deposited.

\section{Faults and structural map of the Bruks Field}

Numerous normal faults are seen on seismic sections, and these can be grouped as major growth faults with associated synthetic and antithetic splays. They trend northeastsouthwest and dip southeast-southwest (Fig. 8). These faulted anticlines are evidence of good hydrocarbon prospects in the study area (Fig. 9). Structures such as collapsed crest and back to back faults also constitute the hydrocarbon trap architecture. The ability of these numerous faults to act as seals depends on the amount of throw and the volume of shale smeared along the faults and the juxtaposition of permeable and impermeable layers 
(reservoirs and seals) across the fault planes. Since the paralic Agbada Formation is of regular alternation of sandshale interval, there is a greater possibility of the shale smear sealing the growth faults and creating the required hydrocarbon traps, though in some cases, they act as migration pathways for oil and gas.

\section{Conclusions}

This study has shown that within the two depositional sequences delineated from the field, the prolific reservoirs are mainly of the lowstand tidally influenced channel and shoreface sands. These sands are correlated across the six wells especially the F-sand reservoir. Some other sands (A-E and G-sands) in the field are deposited in varying environments as distributary and tidal channels, foreshore and shoreface environments. The reservoirs span through shallow inner neritic to middle neritic and constitute mostly of shelf deposits. There is appreciable sand development distally, which confirms that the delta was continuously prograding, due to consistent supply of clastics. The results from porosity to permeability confirm that the F-sand has moderate to good reservoir quality. Its average water saturation of $14 \%$ and to $85 \%$ hydrocarbon saturation is an indication that the F-sand reservoir is charged with a significant volume of hydrocarbons. The structural analysis also confirms that there are numerous faulted anticlines, which is an evidence of good hydrocarbon prospects in the area. The study has shown that reservoir characterization studies using sequence stratigraphic and petrophysical methods have enabled a better understanding of the reservoir quality, heterogeneities and lateral extent within the basin.

Open Access This article is distributed under the terms of the Creative Commons Attribution 4.0 International License (http:// creativecommons.org/licenses/by/4.0/), which permits unrestricted use, distribution, and reproduction in any medium, provided you give appropriate credit to the original author(s) and the source, provide a link to the Creative Commons license, and indicate if changes were made.

\section{References}

Ajaegwu NE, Odoh BI, Akpunonu EO, Obiadi II, Anakwuba EK (2012) Late Miocene to early Pliocene palynostratigraphy and palaeoenvironments of ANE-1 well, eastern Niger Delta, Nigeria. J Min Geol 48(1):31-43
Allen JRL (1965) Late quaternary Niger Delta and adjacent areas: sedimentary environments and lithofacies. Am Assoc Pet Geol Bull 49:547-600

Allen JRL (1970) Sediments of the modern Niger Delta, a summary and review. In: Morgan JP, Shaver RH (eds) Deltaic sedimentation, modern and ancient, vol 15. SEPM Special publication, Tulsa, pp 138-151

Asquith G, Krygowski D (2004) Basic well log analysis. Methods in exploration series, vol 16. American Association of Petroleum Geologist (AAPG), Tulsa

Burke K (1972) Longshore drift, submarine canyons and submarine fans in development of Niger Delta. Am Assoc Pet Geol Bull 56:1975-1983

Darling T (2005) Well logging and formation evaluation. Elsevier Publications, Amsterdam

Doust DM, Omatsola E (1990) Divergent/passive margin basins. In: Edwards JD, Santogrossi PA (eds) Niger Delta, vol 48. American Association of Petroleum Geologists Memoir, Tulsa, pp 239-248

Evamy BD, Harembourne J, Kamerling P, Knaap WA, Molloy FA, Rowlands PH (1978) Hydrocarbon habitat of Tertiary Niger Delta. AAPG Bull 62(1):1-39

Galloway WE (1989) Genetic stratigraphic sequences in basin analysis I, Architecture and genesis of flooding-surface bounded depositional units. AAPG Bull 73(2):125-142

Helland-Hansen W, Hampsen GJ (2009) Trajectory analysis: concepts and analysis. Basin Res 21:454-483

Kendall C (2003) Use of well logs for sequence stratigraphic interpretation of the subsurface. USC Sequence stratigraphy web. http://strata.geol.sc.edu/index.html. University of south Carolina

Lawrence SR, Munday S, Bray R (2002) Regional Geology and geophysics of the eastern Gulf of Guinea (Niger Delta to Rio Muni). Lead Edge 21(11):1112-1117

Mode AW, Adepehin EJ, Anyiam OA (2013) Petrophysical effects of clay heterogeneity on reservoirs' properties: case study of "Brown Field" Niger Delta, Nigeria. Niger Assoc Pet Explor Bull 25(1):61-69

Reijers TJA, Petters SW, Nwajide CS (1997) The Niger Delta Basin. In: Selley RC (ed) African Basins sedimentary; Basins of the world, vol 3. Elsevier, Amsterdam, pp 151-172

Selley RC (1985) Elements of petroleum geology. W.H. Freeman and company, New York

Selley RC (1998) Elements of petroleum geology. Academic Press, San Diego, USA, p 470

Thomas EC, Stieber SJ (1975) The distribution of shale in sandstones and its effect upon porosity. In: Translations of the 16th annual logging symposium of the SPWLA

Vail PR (1987) Seismic stratigraphy interpretation procedures. In: Bally AW (ed) Atlas of seismic stratigraphy. AAPG Studies in Geology, vol 1, no 27, pp 1-10

Van Wagoner JC, Mitchum RM, Campion KM, Rahmanian VD (1990) Siliciclastic sequence stratigraphy in well logs, cores, and outcrops. AAPG Methods in Exploration Series, vol 7. Tulsa, Oklahoma, p 55

Weber KJ (1986) Hydrocarbon distribution patterns in Nigerian growth fault structures controlled by structural style and stratigraphy. Am Assoc Pet Geol Bull 70:661-662 